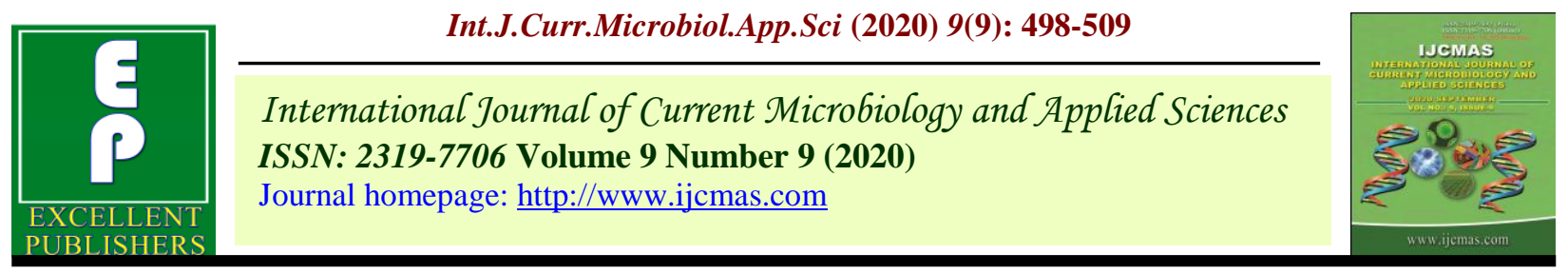

Original Research Article

https://doi.org/10.20546/ijcmas.2020.909.063

\title{
Influence of Combinations of Different Fodder Crops on Growth and Biomass Yield under Hydroponic Condition
}

\author{
Sauvik Ganguly, B. S. Lalitha*, Gurunath Raddy and R. M. Salman Khan \\ Department of Agronomy, University of Agricultural Sciences, GKVK, Bengaluru-65, India \\ *Corresponding author
}

A B S T R A C T

\begin{tabular}{|l|}
\hline Ke y w o r d s \\
Biomass Yield, \\
$\begin{array}{l}\text { Fodder crops, } \\
\text { Growth, } \\
\text { Hydroponics, Water } \\
\text { productivity }\end{array}$ \\
\hline Article Info \\
\hline $\begin{array}{l}\text { Accepted: } \\
\text { 15 August } 2020 \\
\text { Available Online: } \\
\text { 10 September } 2020\end{array}$ \\
\hline
\end{tabular}

\section{Introduction}

In India, to meet out the nutritional and economic security for small and marginal farmers livestock plays a major role. The livestock population of India is 512.1 million including 190.9 million cattle (37.27\%), 108.1 million buffaloes $(21.10 \%), 65.1$ million sheep $(12.71 \%)$ and 135.2 million goats (26.40\%) (Anon., 2017). During last 61 years (1951-2012),the growth rate shows increasing trend in cattle $(28.17 \%)$, buffaloes $(142.7 \%)$, sheep $(83.01 \%)$ and goat $(197.7 \%)$ population and the overall growth rate in livestock is 80.89\% (Anon.,2012). This increasing trend in the livestock population along with the
An experiment was conducted to study the influence of combinations of different fodder crops on growth and biomass yield under hydroponic condition at Agronomy field unit, Zonal Agricultural Research Station, Gandhi Krishi Vignana Kendra, University of Agricultural Sciences, Bangalore during the year 2018. The experiment was conducted with 13 forterent proportions by using completely randomised design Maize treatment recorded significantly higher shoot length $(19.39 \mathrm{~cm})$, root length $(17.61 \mathrm{~cm})$, seedling vigour index (3396), green biomass yield $\left(14.10 \mathrm{~kg} \mathrm{~m}^{-2}\right)$ compared to other treatments. intensive rearing system has resulted in the increase demands for feeds and fodder in the country. A good fodder supply is required for better livestock production and there is huge gap between demand and supply of green fodder and situation worsen during summer.

The land available for cultivation of green fodder is very limited (only 5\% of the gross cropped area); but by 2020, India would require a total 526, 855 and 56 million tons of dry fodder, green fodder and concentrates, respectively (Dikshit and Brithal, 2010). So, there is need for an alternative green fodder production system to meet the demand of the growing livestock population. The best 
alternate method for fodder cultivation is hydroponic fodder cultivation. Hydroponic is basically growing plants without soil and the word hydroponic has been derived from the Greek word 'water working'. Hydro means 'water' and ponic means 'working'. It is done either through solution culture (placing the plants in a container of solution), or through medium culture (using another medium such as gravelor sand). It is becoming more and more common in countries where the outdoors is more vulnerable to climate change. It can be practiced in indoors and is more effective this way, as we can control the climate, and ensures a high yield. For arid, dry climates or areas with short growing season hydroponic thus holds a better solution. Further, hydroponics require 1 to 2 litres of water to produce 1 kilogram of fodder when compared to conventional fodder production require 80-90 litres of water to grow 1kilogram of green fodder. High water productivity is a major advantage of this technique and which saves about 95-97 per cent of water along with land required for fodder cultivation in conventional system (AlKaraki and Al-Hasimi, 2012). Hydroponics is one of the best ways to get nutritionally rich fodder with high yield over shorter period of time when land available for fodder cultivation is limiting factor.

\section{Materials and Methods}

The experiment was conducted at Agronomy field unit, ZARS, University of Agricultural Sciences, GKVK, Bengaluru. It comes under Eastern Dry Zone (Zone-V) of Karnataka situated at latitude of $13.08^{\circ} \mathrm{N}$ and longitude of $77.59^{\circ} \mathrm{E}$ with at an altitude of 930 meter above mean sea level. The hydroponic unit was designed with three stands, each of them having width of $75 \mathrm{~cm}$ and a height of $170 \mathrm{~cm}$ accommodating 5 trays. Each tray was made with vinyl fibre of dimensions $2.5 \mathrm{ft} \times 1.5 \mathrm{ft} \times$ $0.15 \mathrm{ft}$. Seeds of maize (South African Tall), finger millet (GPU 48), little millet (JK-8) and cowpea (KBC-2) were weighed and washed with freshwater and then soaked in fresh water for 24 hours in 1:2 proportion (1 part of seeds and 2 parts of water). After 24 hours the water was drained out and the seeds were then tied in a gunny bag and kept in dark. Water was sprinkled at 2-3 hours interval and incubated for another 24 hours for proper germination. After 24 hours, germinated seeds were transferred to trays and covered by wet gunny bag for 2-3 days for better growth and establishment. Later gunny bag was removed and trays were exposed to sunlight and watering was done as and when required. The samples were collected at $5^{\text {th }}, 10^{\text {th }}$ and $14^{\text {th }}$ days after sowing for proximate analysis.

The treatment details are $\mathrm{T}_{1}: 100 \%$ Finger millet, $\mathrm{T}_{2}: 75 \%$ Finger millet $+25 \%$ Cowpea, $\mathrm{T}_{3}: 50 \%$ Finger millet $+50 \%$ Cowpea, $\mathrm{T}_{4}$ : $25 \%$ Finger millet $+75 \%$ Cowpea, $\mathrm{T}_{5}: 100 \%$ Little millet, $\mathrm{T}_{6}: 75 \%$ Little millet $+25 \%$ Cowpea, $\mathrm{T}_{7}: 50 \%$ Little millet $+50 \%$ Cowpea, $\mathrm{T}_{8}: 25 \%$ Little millet $+75 \%$ Cowpea, $\mathrm{T}_{9}: 100 \%$ Maize, $\mathrm{T}_{10}: 75 \%$ Maize + $25 \%$ Cowpea, $\mathrm{T}_{11}: 50 \%$ Maize $+50 \%$ Cowpea, $\mathrm{T}_{12}: 25 \%$ Maize $+75 \%$ Cowpea, $\mathrm{T}_{13}: 100 \%$ Cowpea.

The total number of seed germinated was counted in an area of $100 \mathrm{~cm}^{2}$ from every tray and germination percentage was calculated by using germination percentage formula \{Germination $(\%)=$ (Number of seeds germinated/Total number of seeds $) \times 100\}$.

Biomass yield was taken at 5, 10 and 14 days after sowing. For $5^{\text {th }}$ and $10^{\text {th }}$ day's observation, biomass yield was measured in weighing machine without harvesting of crops. The crops were finally harvested on 14 days after sowing and biomass yield from each tray was recorded separately in weighing machine as per the treatments. For all 
observations, fresh weight was expressed as $\mathrm{kg}$ tray $^{-1}$ and later converted into $\mathrm{kg} \mathrm{m}^{-2}$. Dry weight was taken at 5, 10 and 14 days after sowing. After recording the fresh weight, the samples were dried at $65^{\circ} \mathrm{C}$ until they attain constant dry weight. Dry weight was recorded and expressed in $\mathrm{kg} \mathrm{m}^{-2}$. The daily added and drained out water from trays throughout the course of experiment were recorded per tray to compute for total water use and water use efficiency or water productivity. The total water used by plants (litres/tray) is calculated using following equation (Al-Ajmi et al., 2009) and expressed in $\mathrm{kg} / \mathrm{litre}$.

Total water use $=$ Total water added - Total drained water out of trays

To work out the economics, the market price of seeds and labour unit for the production of hydroponic fodder was considered. Cost of labour was calculated by taking into account the prevailing labour wages at the time of investigation. The prevailing prices of inputs and labour cost were considered for computing the cost of cultivation and expressed in rupees per square meter. Gross return per meter square was calculated by taking into consideration the price of the fresh fodder that was prevailing in the market. Net returns were calculated treatment-wise by deducting cost of cultivation from gross returns.

\section{Results and Discussion}

Growth parameters and biomass yield attributes of fodder crops as influenced by different treatment combinations

\section{Germination percentage}

The highest germination percentage was found in 50\% Little millet $+50 \%$ Cowpea $(93.68 \%)$ followed by $75 \%$ Little millet + $25 \%$ Cowpea (93.25\%). Lowest germination percentage was recorded in $75 \%$ Finger millet
$+25 \%$ Cowpea (91.56\%). This was might be due to proper availability of water (moisture), oxygen and temperature to the seeds during the time of pre-germination of seeds before sowing. As well as, those seeds had good viability, high genetic purity, physical purity and less dormancy percentage. The data on germination percentage of different crops as influenced by treatment combinations is presented in table 1 .

\section{Shoot length}

At 5 DAS, $100 \%$ Maize treatment recorded significantly higher $(5.95 \mathrm{~cm})$ shoot length compared to all other treatments and significantly lower shoot length were observed at $100 \%$ Little millet $(1.78 \mathrm{~cm})$. At 10 DAS, significantly higher shoot length was observed at $100 \%$ Maize $(15.26 \mathrm{~cm})$ compared to all other treatments. The next best treatment with respect to shoot length is $75 \%$ Maize $+25 \%$ Cowpea $(11.84 \mathrm{~cm})$. Significantly lower shoot length was recorded at $100 \%$ Little millet $(3.59 \mathrm{~cm})$. At 14 DAS (harvest), $100 \%$ Maize treatment recorded significantly higher shoot length $(19.39 \mathrm{~cm})$ compared to all other treatments. Significantly lower shoot length was observed at $100 \%$ Little millet $(4.07 \mathrm{~cm})$. The higher shoot length of $100 \%$ Maize may be due to quick establishment, good seedling vigour and fast growth of maize seedlings within short period of time. On the other side, millet seedlings having less seedling vigour index, slow establishment and slow growth with respect to time. Apart from that, the shoot length of $100 \%$ Cowpea is moderate as seedling vigour index of cowpea is not as high as of maize. In maize + cowpea treatments, though the maize seedlings having good vigour but due to inter plant competition with cowpea seedlings, the average shoot length of those treatments was less than that of $100 \%$ Maize treatment. In those treatment combinations, where the maize proportion is 
high, average shoot length was more as in that case maize seedlings can somewhat nullify the dominance of cowpea seedlings. As the proportion of cowpea increases, average shoot length also decreases. In case of millet + cowpea treatments, average shoot length has showed variation due to differential establishment and seedling vigour index of millet and cowpea seedlings. The results are in conformity with the findings of Naik and Singh (2013) and Naik et al., (2016). The data on shoot length $(\mathrm{cm})$ of different crops as influenced by treatment combinations is presented in table 2 .

\section{Root length}

At 5 DAS $100 \%$ Maize treatment recorded significantly higher $(5.01 \mathrm{~cm})$ root length compared to rest of the treatments and significantly lower root length was observed at $100 \%$ Little millet $(1.65 \mathrm{~cm})$. At 10 DAS, significantly higher root length was observed at $100 \%$ Maize $(13.65 \mathrm{~cm})$ compared to rest of the treatments. Significantly lower root length was recorded at $100 \%$ Little millet $(3.15 \mathrm{~cm})$. At 14 DAS (harvest), 100\% Maize recorded significantly higher root length $(17.61 \mathrm{~cm})$ compared to all other treatments and significantly lower root length was observed at $100 \%$ Little millet $(3.68 \mathrm{~cm})$. The higher root length of $100 \%$ Maize may be due to quick establishment, good seedling vigour and fast growth of maize seedlings within short period of time. Root elongation and branching are interactive processes in maize root development which is typically influenced by high seedling vigour. This is in conformity with the findings of Naik and Singh (2013). Variations in the attributes of elongation and branching create morphological differences in root lengths, numbers and diameters of crops. As the maize crop duration is of 14 days, among the embryonic and postembryonic root types, embryonically performed roots (fibrous toot) dominate the seedling root system. On the other side, due to low seedling vigour and slow growth, millet seedlings have given shorter root length. Apart from that, the root length of $100 \%$ Cowpea is moderate as seedling vigour index of cowpea is not as high as of maize. Maize and cowpea are having fibrous and tap root respectively. In maize + cowpea treatments, due to dissimilarity of this root systems, both type of seedlings has faced a tremendous inter plant competition than that of their homogeneous condition. Basically, in those treatments, root length of cowpea seedlings is less due to their nature of the root and less seedling vigour. In most of the cases, maize root length growth has overtaken Cowpea root growth, as rate of increase of fibrous root is more than tap root in favourable (sufficient resource) condition. In those treatment combinations, where the maize proportion is high, average root length is more as in that case maize seedlings can somewhat nullify the dominance of cowpea seedlings $(3.43,3.42$ and $3.24 \mathrm{~cm}$ in $75 \%$ Maize $+25 \%$ Cowpea, $50 \%$ Maize $+50 \%$ Cowpea and 25\% Maize $+75 \%$ Cowpea, respectively at $5 \mathrm{DAS}$ ). As the proportion of cowpea increases, average root length also decreases. In case of millet + cowpea treatments, average root length has showed variation due to differential establishment and seedling vigour index of millet and cowpea seedlings. The results are in conformity with the findings of Naik et al., (2016). The data on root length $(\mathrm{cm})$ of different crops as influenced by treatment combinations is presented in table 3 .

\section{Seedling vigour index}

At 5 DAS, significantly higher seedling vigour index was found in $100 \%$ Maize (1007). The next best treatments with respect to seedling vigour are $75 \%$ Maize $+25 \%$ Cowpea (737) and 50\% Maize $+50 \%$ Cowpea (730). Significantly lower seedling 
vigour index were found in $100 \%$ Little millet (315) and 100\% Finger millet (357). At 10 DAS, $100 \%$ Maize recorded significantly higher seedling vigour index $(2,655)$ compared to rest of the treatments. The next best treatment with respect to seedling vigour index is $75 \%$ Maize $+25 \%$ Cowpea (2026). Significantly lower seedling vigour was recorded at $100 \%$ Little millet (619). At 14 DAS (harvest), $100 \%$ Maize recorded significantly higher seedling vigour (3396) compared to all other treatments. Significantly lower seedling vigour index was found in 100\% Small millet (713). Seedling vigour index is an important trait for crop establishment and uniform growth of crop. It will influence growth and yield of crop. The seedling vigour is directly correlated to shoot length, root length and germination percentage of crops. Increase in shoot length, root length and germination percentage of the crops are responsible for higher seedling vigour. The increased shoot length and root length of maize in the experiment increased the seedling vigour of $100 \%$ Maize treatment as compared to other crops. Though there is not so much variation in germination percentage among the treatments but due to variation in shoot and root length, seedling vigour in each treatment changes drastically. The results are in conformity with the findings of Naik and Singh (2013). The data on seedling vigour index of different crops as influenced by treatment combinations is presented in table 4.

\section{Dry weight}

At 5 DAS, 100\% Maize recorded significantly higher dry weight $(1.85 \mathrm{~kg} / \mathrm{m} 2)$ compared to all other treatments. It was at par with $75 \%$ Maize $+25 \%$ Cowpea $(1.76 \mathrm{~kg} / \mathrm{m} 2)$. Significantly lower dry weight was observed at $100 \%$ Little millet $(0.58 \mathrm{~kg} / \mathrm{m} 2)$. At 10 DAS, significantly higher dry weight was found in $100 \%$ Maize $(1.97 \mathrm{~kg} / \mathrm{m} 2)$. It was at par with $75 \%$ Maize $+25 \%$ Cowpea (1.90 $\mathrm{kg} / \mathrm{m} 2$ ). Significantly lower dry matter yield was recorded at $100 \%$ Little millet $(0.90$ $\mathrm{kg} / \mathrm{m} 2$ ). At 14 DAS (harvest), 100\% Maize treatment recorded significantly higher dry weight $(2.68 \mathrm{~kg} / \mathrm{m} 2)$ compared to rest of the treatments. Significantly lower dry weight was found in $100 \%$ Little millet $(1.24 \mathrm{~kg} / \mathrm{m} 2)$. The higher dry weight of $100 \%$ Maize is directly related to total dry matter accumulation. Pattern and rate of dry matter accumulation in a crop typically follows a sigmoid curve. Dry weight varies with the different growth stages of the crop. Higher dry matter accumulation during different growth stages of $100 \%$ Maize was mainly ascribed to increased photosynthetic ability and their partitioning to different parts with the advancement of age with respect to different treatment combinations. The lower yield of dry matter of millets (100\% Little millet and $100 \%$ Finger Millet) was might be due to low enzymatic activity in growing plant which led to depletion of food reserves of the seed endosperm resulted in little chance for dry matter accumulation. These results corroborated with the findings of Dung et al., (2010). The data on dry weight $(\mathrm{kg} / \mathrm{m} 2)$ of different crops as influenced by treatment combinations is presented in fig. 1 .

\section{Biomass yield of different fodder crops as influenced by different treatment combinations}

At 5 DAS, 100\% Maize treatment recorded significantly higher biomass yield $(7.85$ $\mathrm{kg} / \mathrm{m} 2$ ) compared to rest of the treatments. It is on par with $75 \%$ Maize $+25 \%$ Cowpea $(7.62 \mathrm{~kg} / \mathrm{m} 2)$. Significantly lower biomass yield was found in $100 \%$ Little millet (3.74 $\mathrm{kg} / \mathrm{m} 2$ ). At 10 DAS, significantly higher biomass yield was observed at $100 \%$ Maize $(11.75 \mathrm{~kg} / \mathrm{m} 2)$ compared to rest of the treatments. Significantly lower biomass yield was recorded at $100 \%$ Little millet $(7.76$ 
$\mathrm{kg} / \mathrm{m} 2$ ). At 14 DAS (harvest), 100\% Maize treatment recorded significantly higher biomass yield $(14.10 \mathrm{~kg} / \mathrm{m} 2)$. Significantly lower biomass yield was found in $100 \%$ Little millet $(9.77 \mathrm{~kg} / \mathrm{m} 2)$. Biomass yield is the outcome of different metabolic activities that takes place in the different stages of growth of the plants. Biomass yield of the fodder crop depends on both external and internal factors. Internal factors like growth and yield parameters viz., dry matter accumulation and distribution in different growth stages, fresh and dry weight of the plants, seedling vigour, shoot length and root length and external factors like optimum light, water and nutrients. The increase in dry matter accumulation in seedlings has increased fresh biomass yield of the hydroponically grown maize, finger millet, Little millet and cowpea with respect to time. Here, the higher green biomass yield in 100\% Maize might be due to higher yield parameters like fresh weight of shoot and roots, higher growth parameter like shoot length $(5.95,15.26$ and $19.39 \mathrm{~cm})$, root length (5.01, 13.65 and $17.61 \mathrm{~cm}$ ) and good seedling vigour index $(1007,2,655$ and 3,396) at 5 DAS, 10 DAS and 14 DAS, respectively. This is in conformity with the findings of Naik (2012). In comparison to millets and cowpea seeds, maize seeds are large and bold in nature which contains more food and nutrient reserve. This can help maize seedlings to supply the required food for longer period of time and to grow with their maximum potential which ultimately results in significantly higher biomass yield. All the Little millet and finger millet and its associated treatments (with cowpea) has given low biomass yield as compared to maize and its associated (with cowpea) treatments. This was might be due to slow growth of millet seedlings with respect to time, less shoot and root length, low seedling vigour index and less food reserve in their small sized seeds. The data on green biomass yield $(\mathrm{kg} / \mathrm{m} 2)$ of different crops as influenced by treatment combinations is presented in table 5 .

Table.1 Germination of hydroponically grown fodder crops as influenced by different treatment combinations

\begin{tabular}{|c|c|}
\hline Treatments & Germination (\%) \\
\hline$T_{1}: 100 \%$ Finger millet & 92.37 \\
\hline$T_{2}: 75 \%$ Finger millet $+25 \%$ Cowpea & 91.56 \\
\hline $\mathrm{T}_{3}: \mathbf{5 0 \%}$ Finger millet $+\mathbf{5 0 \%}$ Cowpea & 91.59 \\
\hline$T_{4}: 25 \%$ Finger millet $+75 \%$ Cowpea & 92.25 \\
\hline$T_{5}: 100 \%$ Little millet & 91.91 \\
\hline $\mathrm{T}_{6}: 75 \%$ Little millet $+25 \%$ Cowpea & 93.25 \\
\hline $\mathrm{T}_{7}: \mathbf{5 0 \%}$ Little millet $+\mathbf{5 0 \%}$ Cowpea & 93.68 \\
\hline $\mathrm{T}_{8}: 25 \%$ Little millet $+75 \%$ Cowpea & 91.57 \\
\hline$T_{9}: 100 \%$ Maize & 91.82 \\
\hline$T_{10}: 75 \%$ Maize $+25 \%$ Cowpea & 92.67 \\
\hline$T_{11}: 50 \%$ Maize $+50 \%$ Cowpea & 92.95 \\
\hline$T_{12}: 25 \%$ Maize $+75 \%$ Cowpea & 92.82 \\
\hline$T_{13}: 100 \%$ Cowpea & 91.63 \\
\hline S.E.m \pm & 0.757 \\
\hline C.D.@1\% & NS \\
\hline
\end{tabular}


Table.2 Shoot length of hydroponically grown fodder crops as influenced by different treatment combinations

\begin{tabular}{|l|c|c|c|}
\hline \multicolumn{1}{|c|}{ Treatments } & \multicolumn{3}{|c|}{ Shoot length (cm) } \\
\cline { 2 - 4 } & 5 DAS & 10 DAS & 14 DAS \\
\hline $\mathbf{T}_{\mathbf{1}}: \mathbf{1 0 0 \%}$ Finger millet & 2.01 & 3.84 & 4.13 \\
\hline $\mathbf{T}_{\mathbf{2}}: \mathbf{7 5 \%}$ Finger millet + 25\% Cowpea & 2.68 & 5.94 & 7.97 \\
\hline $\mathbf{T}_{\mathbf{3}}: \mathbf{5 0 \%}$ Finger millet + 50\% Cowpea & 2.45 & 5.92 & 7.96 \\
\hline $\mathbf{T}_{\mathbf{4}}: \mathbf{2 5 \%}$ Finger millet + 75\% Cowpea & 2.37 & 5.82 & 7.73 \\
\hline $\mathbf{T}_{\mathbf{5}}: \mathbf{1 0 0 \%}$ Little millet & 1.78 & 3.59 & 4.07 \\
\hline $\mathbf{T}_{\mathbf{6}}: \mathbf{7 5 \%}$ Little millet + 25\% Cowpea & 2.30 & 5.56 & 7.81 \\
\hline $\mathbf{T}_{\mathbf{7}}: \mathbf{5 0 \%}$ Little millet + 50\% Cowpea & 2.33 & 5.56 & 7.79 \\
\hline $\mathbf{T}_{\mathbf{8}}: \mathbf{2 5 \%}$ Little millet + 75\% Cowpea & 2.16 & 5.42 & 7.77 \\
\hline $\mathbf{T}_{\mathbf{9}}: \mathbf{1 0 0 \%}$ Maize & 5.95 & 15.26 & 19.39 \\
\hline $\mathbf{T}_{\mathbf{1 0}}: \mathbf{7 5 \%}$ Maize + 25\% Cowpea & 4.52 & 11.84 & 15.27 \\
\hline $\mathbf{T}_{\mathbf{1 1}}: \mathbf{5 0 \%}$ Maize + 50\% Cowpea & 4.44 & 11.04 & 15.07 \\
\hline $\mathbf{T}_{\mathbf{1 2}}: \mathbf{2 5 \%}$ Maize + 75\% Cowpea & 4.11 & 10.80 & 14.83 \\
\hline $\mathbf{T}_{\mathbf{1 3}}: \mathbf{1 0 0 \%}$ Cowpea & 3.50 & 8.59 & 11.63 \\
\hline S.E.m \pm & 0.08 & 0.163 & 0.26 \\
\hline C.D. @ 1\% & 0.235 & 0.475 & 0.761 \\
\hline
\end{tabular}

Table.3 Root length of hydroponically grown fodder crops as influenced by different treatment combinations

\begin{tabular}{|l|c|c|c|}
\hline \multirow{2}{*}{ Treatments } & \multicolumn{3}{|c|}{ Root length (cm) } \\
\cline { 2 - 3 } & 5 DAS & 10 DAS & 14 DAS \\
\hline $\mathbf{T}_{\mathbf{1}}: \mathbf{1 0 0 \%}$ Finger millet & 1.86 & 3.32 & 3.69 \\
\hline $\mathbf{T}_{\mathbf{2}}: \mathbf{7 5 \%}$ Finger millet + 25\% Cowpea & 2.19 & 5.48 & 6.85 \\
\hline $\mathbf{T}_{\mathbf{3}}: \mathbf{5 0 \%}$ Finger millet + 50\% Cowpea & 2.19 & 5.42 & 6.94 \\
\hline $\mathbf{T}_{\mathbf{4}}: \mathbf{2 5 \%}$ Finger millet + 75\% Cowpea & 2.12 & 5.49 & 7.08 \\
\hline $\mathbf{T}_{\mathbf{5}}: \mathbf{1 0 0 \%}$ Little millet & 1.65 & 3.15 & 3.68 \\
\hline $\mathbf{T}_{\mathbf{6}}: \mathbf{7 5 \%}$ Little millet + 25\% Cowpea & 2.07 & 5.16 & 7.34 \\
\hline $\mathbf{T}_{\mathbf{7}}: \mathbf{5 0 \%}$ Little millet + 50\% Cowpea & 2.12 & 5.23 & 7.00 \\
\hline $\mathbf{T}_{\mathbf{8}}: \mathbf{2 5 \%}$ Little millet + 75\% Cowpea & 2.04 & 5.21 & 7.11 \\
\hline $\mathbf{T}_{\mathbf{9}}: \mathbf{1 0 0 \%}$ Maize & 5.01 & 13.65 & 17.61 \\
\hline $\mathbf{T}_{\mathbf{1 0}}: \mathbf{7 5 \%}$ Maize + 25\% Cowpea & 3.43 & 10.03 & 14.30 \\
\hline $\mathbf{T}_{\mathbf{1 1}}: \mathbf{5 0 \%}$ Maize + 50\% Cowpea & 3.42 & 9.68 & 14.15 \\
\hline $\mathbf{T}_{\mathbf{1 2}}: \mathbf{2 5 \%}$ Maize + 75\% Cowpea & 3.24 & 9.64 & 13.71 \\
\hline $\mathbf{T}_{\mathbf{1 3}}: \mathbf{1 0 0 \%}$ Cowpea & 2.70 & 6.80 & 10.88 \\
\hline S.E.m \pm & 0.05 & 0.135 & 0.212 \\
\hline C.D. @ 1\% & 0.147 & 0.393 & 0.621 \\
\hline
\end{tabular}


Table.4 Seedling vigour index of hydroponically grown fodder crops as influenced by different treatment combinations

\begin{tabular}{|c|c|c|c|}
\hline \multirow[t]{2}{*}{ Treatments } & \multicolumn{3}{|c|}{ Seedling vigour index } \\
\hline & 5 DAS & $10 \mathrm{DAS}$ & 14 DAS \\
\hline $\mathrm{T}_{1}: 100 \%$ Finger millet & 357 & 662 & 722 \\
\hline $\mathrm{T}_{2}: \mathbf{7 5 \%}$ Finger millet $+25 \%$ Cowpea & 447 & 1046 & 1357 \\
\hline $\mathrm{T}_{3}: \mathbf{5 0 \%}$ Finger millet $+\mathbf{5 0 \%}$ Cowpea & 424 & 1039 & 1365 \\
\hline $\mathrm{T}_{4}: \mathbf{2 5 \%}$ Finger millet $+\mathbf{7 5 \%}$ Cowpea & 414 & 1043 & 1367 \\
\hline$T_{5}: 100 \%$ Little millet & 315 & 619 & 713 \\
\hline $\mathrm{T}_{6}: \mathbf{7 5 \%}$ Little millet $+25 \%$ Cowpea & 407 & 1000 & 1413 \\
\hline $\mathrm{T}_{7}: 50 \%$ Little millet $+50 \%$ Cowpea & 417 & 1010 & 1386 \\
\hline $\mathrm{T}_{8}: 25 \%$ Little millet + $75 \%$ Cowpea & 384 & 974 & 1365 \\
\hline$T_{9}: 100 \%$ Maize & 1007 & 2655 & 3396 \\
\hline$T_{10}: 75 \%$ Maize $+25 \%$ Cowpea & 737 & 2026 & 2740 \\
\hline $\mathrm{T}_{11}: \mathbf{5 0 \%}$ Maize $+\mathbf{5 0 \%}$ Cowpea & 730 & 1926 & 2716 \\
\hline$T_{12}: 25 \%$ Maize $+75 \%$ Cowpea & 682 & 1897 & 2649 \\
\hline$T_{13}: 100 \%$ Cowpea & 568 & 1410 & 2063 \\
\hline S.E.m \pm & 11.90 & 29.41 & 98.32 \\
\hline C.D. @ 1\% & 34.79 & 85.95 & 287.40 \\
\hline
\end{tabular}

Table.5 Biomass yield of hydroponically grown fodder crops as influenced by different treatment combinations

\begin{tabular}{|c|c|c|c|}
\hline \multirow[t]{2}{*}{ Treatments } & \multicolumn{3}{|c|}{ Biomass yield $\left(\mathrm{kg} / \mathrm{m}^{2}\right)$} \\
\hline & $5 \mathrm{DAS}$ & 10 DAS & 14 DAS \\
\hline$T_{1}: 100 \%$ Finger millet & 4.34 & 8.37 & 10.27 \\
\hline $\mathrm{T}_{2}: \mathbf{7 5} \%$ Finger millet $+25 \%$ Cowpea & 4.42 & 8.49 & 10.66 \\
\hline $\mathrm{T}_{3}: \mathbf{5 0 \%}$ Finger millet $+50 \%$ Cowpea & 4.67 & 8.95 & 11.01 \\
\hline $\mathrm{T}_{4}: \mathbf{2 5 \%}$ Finger millet $+\mathbf{7 5 \%}$ Cowpea & 5.64 & 9.03 & 11.81 \\
\hline$T_{5}: 100 \%$ Little millet & 3.74 & 7.76 & 9.77 \\
\hline$T_{6}: 75 \%$ Little millet $+25 \%$ Cowpea & 4.44 & 8.01 & 10.59 \\
\hline $\mathbf{T}_{7}: 50 \%$ Little millet $+\mathbf{5 0 \%}$ Cowpea & 5.11 & 9.05 & 11.12 \\
\hline$T_{8}: 25 \%$ Little millet $+75 \%$ Cowpea & 5.56 & 9.14 & 11.66 \\
\hline$T_{9}: 100 \%$ Maize & 7.85 & 11.75 & 14.10 \\
\hline$T_{10}: 75 \%$ Maize $+25 \%$ Cowpea & 7.62 & 11.55 & 13.67 \\
\hline$T_{11}: 50 \%$ Maize $+50 \%$ Cowpea & 7.13 & 11.43 & 13.25 \\
\hline$T_{12}: 25 \%$ Maize $+75 \%$ Cowpea & 6.59 & 10.04 & 12.61 \\
\hline$T_{13}: 100 \%$ Cowpea & 6.16 & 9.74 & 12.25 \\
\hline S.E.m \pm & 0.1 & 0.055 & 0.118 \\
\hline C.D.@1\% & 0.292 & 0.16 & 0.344 \\
\hline
\end{tabular}


Table.6 Water productivity of hydroponically grown fodder crops as influenced by different treatment combinations

\begin{tabular}{|c|c|c|c|}
\hline \multirow[t]{2}{*}{ Treatments } & \multicolumn{3}{|c|}{ Water productivity (kg/litre) } \\
\hline & $5 \mathrm{DAS}$ & $10 \mathrm{DAS}$ & 14 DAS \\
\hline $\mathrm{T}_{1}: \mathbf{1 0 0 \%}$ Finger millet & 22.36 & 21.07 & 19.19 \\
\hline $\mathrm{T}_{2}: \mathbf{7 5 \%}$ Finger millet $+25 \%$ Cowpea & 21.41 & 20.42 & 18.37 \\
\hline$T_{3}: 50 \%$ Finger millet $+50 \%$ Cowpea & 20.17 & 19.16 & 16.36 \\
\hline $\mathrm{T}_{4}: 25 \%$ Finger millet $+75 \%$ Cowpea & 19.28 & 18.71 & 15.70 \\
\hline$T_{5}: 100 \%$ Little millet & 21.69 & 20.63 & 18.63 \\
\hline$T_{6}: 75 \%$ Little millet $+25 \%$ Cowpea & 20.95 & 20.28 & 17.51 \\
\hline$T_{7}: 50 \%$ Little millet $+\mathbf{5 0 \%}$ Cowpea & 19.94 & 18.90 & 16.22 \\
\hline$T_{8}: 25 \%$ Little millet $+75 \%$ Cowpea & 19.15 & 18.35 & 15.31 \\
\hline$T_{9}: 100 \%$ Maize & 16.94 & 15.99 & 13.16 \\
\hline $\mathrm{T}_{10}: 75 \%$ Maize $+25 \%$ Cowpea & 18.11 & 17.12 & 14.07 \\
\hline $\mathrm{T}_{11}: \mathbf{5 0 \%}$ Maize $+\mathbf{5 0 \%}$ Cowpea & 18.67 & 17.77 & 14.63 \\
\hline $\mathbf{T}_{12}: 25 \%$ Maize $+75 \%$ Cowpea & 18.68 & 17.87 & 14.86 \\
\hline $\mathbf{T}_{13}: \mathbf{1 0 0 \%}$ Cowpea & 19.36 & 18.17 & 15.39 \\
\hline S.E.m \pm & 0.055 & 0.098 & 0.136 \\
\hline C.D.@1\% & 0.161 & 0.287 & 0.399 \\
\hline
\end{tabular}

Table.7 Economics of hydroponically grown fodder crops under different treatment combinations

\begin{tabular}{|c|c|c|c|c|}
\hline Treatments & $\begin{array}{c}\text { Total Cost } \\
(\text { Rs./ m²) }\end{array}$ & $\begin{array}{l}\text { Gross Return } \\
\quad\left(\text { Rs. } / \mathbf{m}^{2}\right)\end{array}$ & $\begin{array}{c}\text { Net Return } \\
(\text { Rs./ m²) }\end{array}$ & $\begin{array}{c}\text { Cost Benefit } \\
\text { Ratio }\end{array}$ \\
\hline $\mathrm{T}_{1}: \mathbf{1 0 0 \%}$ Finger millet & 136.0 & 328.0 & 192.0 & 2.41 \\
\hline$T_{2}: 75 \%$ Finger millet $+25 \%$ Cowpea & 142.0 & 335.8 & 193.8 & 2.36 \\
\hline $\mathrm{T}_{3}: \mathbf{5 0 \%}$ Finger millet $+\mathbf{5 0 \%}$ Cowpea & 148.0 & 341.0 & 193.0 & 2.30 \\
\hline$T_{4}: 25 \%$ Finger millet $+75 \%$ Cowpea & 154.0 & 360.2 & 206.2 & 2.33 \\
\hline$T_{5}: 100 \%$ Little millet & 135.0 & 273.6 & 138.6 & 2.03 \\
\hline$T_{6}: 75 \%$ Little millet $+25 \%$ Cowpea & 141.3 & 301.8 & 160.5 & 2.13 \\
\hline $\mathrm{T}_{7}: \mathbf{5 0 \%}$ Little millet $+\mathbf{5 0 \%}$ Cowpea & 147.5 & 322.5 & 175.0 & 2.18 \\
\hline$T_{8}: 25 \%$ Little millet $+75 \%$ Cowpea & 153.8 & 343.5 & 189.7 & 2.24 \\
\hline$T_{9}: 100 \%$ Maize & 135.0 & 479.4 & 344.4 & 3.55 \\
\hline$T_{10}: 75 \%$ Maize $+25 \%$ Cowpea & 141.3 & 451.1 & 309.8 & 3.19 \\
\hline$T_{11}: 50 \%$ Maize $+\mathbf{5 0 \%}$ Cowpea & 147.5 & 424.0 & 276.5 & 2.87 \\
\hline$T_{12}: 25 \%$ Maize $+75 \%$ Cowpea & 153.8 & 390.9 & 237.1 & 2.54 \\
\hline$T_{13}: 100 \%$ Cowpea & 160.0 & 367.5 & 207.5 & 2.30 \\
\hline
\end{tabular}


Fig.1 Dry weight of hydroponically grown fodder crops as influenced by different treatment combinations

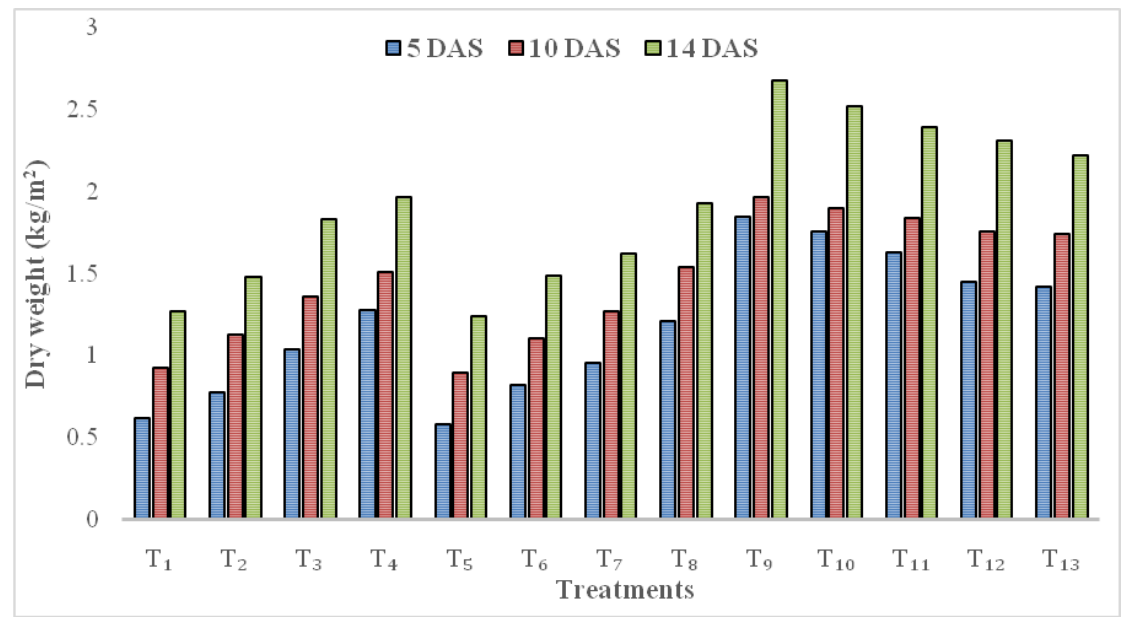

\section{Water productivity}

At 5 DAS, $100 \%$ Finger millet recorded significantly higher water productivity (22.36 $\mathrm{kg} / \mathrm{litre})$. Significantly lower water productivity was found in $100 \%$ Maize (16.94 $\mathrm{kg} / \mathrm{litre})$. Significantly higher water productivity ( $\mathrm{kg} /$ litre) next to $100 \%$ Finger millet was found in $100 \%$ Little millet treatment $(21.69 \mathrm{~kg} / \mathrm{litre})$. At $10 \mathrm{DAS}$, significantly higher water productivity was found in $100 \%$ Finger millet $(21.07 \mathrm{~kg} /$ litre $)$. The water productivity next to $100 \%$ Finger millet were found in $100 \%$ Little Millet $(20.63 \mathrm{~kg} /$ litre) and $75 \%$ Finger millet $+25 \%$ Cowpea $(20.42 \mathrm{~kg} / \mathrm{litre})$. At harvest, the water productivity of $100 \%$ Finger millet was recorded significantly higher $(19.19 \mathrm{~kg} / \mathrm{litre})$. Significantly lower water productivity was found in $100 \%$ Maize $(13.16 \mathrm{~kg} / \mathrm{litre})$. All the millets and millet based cowpea treatments has given higher water productivity. This might be due to their less requirement of water compared to other crops taken in this experiment. Side by side, millets have the capability to combat with extreme environmental conditions especially to inadequate moisture or in drought conditions. On the other side, water requirement of maize seedlings is higher than the other crops taken in the experiment. Cowpea has taken less water than maize but more with compare to millets. For that the treatments having more cowpea proportion with millets has shown less water productivity with compare to $100 \%$ Finger millet or $100 \%$ Little millet and treatments having more cowpea proportion with maize has shown more water productivity with compare to $100 \%$ Maize. In general, water productivity of each treatment has been decreased with respect to time. This was might be due to the increase in dry matter accumulation in seedlings which has increased fresh biomass yield of the hydroponically grown maize, finger millet, Little millet and cowpea with respect to time, hence also the water requirement. The results are in conformation with the results of Mutum Lamnganbi and Surve, (2017). The data on water productivity (kg/litre) of different crops as influenced by treatment combinations is presented in table 6 .

\section{Economics}

Among different treatments, 100\% Maize recorded higher gross return (Rs.479.4/. ${ }^{2}$ ) followed by in $75 \%$ Maize $+25 \%$ Cowpea (Rs.451.1/ $\mathrm{m}^{2}$ ). The lowest gross return has obtained from 100\% Little millet (Rs.273.6/ 
$\mathrm{m}^{2}$ ). $100 \%$ Maize recorded higher net return (Rs.344.4/ $\mathrm{m}^{2}$ ) among different treatments taken in experiment followed by in $75 \%$ Maize + 25\% Cowpea (Rs.309.8/ $\mathrm{m}^{2}$ ). The lowest net return has obtained from $100 \%$ Little millet (Rs.138.6/ $\mathrm{m}^{2}$ ). Among different treatments, $100 \%$ Maize recorded higher cost benefit ratio (3.55) followed by in 75\% Maize $+25 \%$ Cowpea (3.19). The lowest cost benefit ratio has obtained from $100 \%$ Little millet (2.03). This might be due to the fact that among the crops taken in experiment, maize has given the highest biomass yield with respect to time in comparison to other treatments and market value of maize fodder is also high. So, it has resulted highest gross return. Besides that, fodder maize seed cost is low with respect to other crops. For that it has generated highest net return and cost benefit ratio. The data pertaining to the economics of hydroponic fodder crops viz. maize, finger millet, Little millet and cowpea as influenced by different treatment combinations are presented in table 7 .

In conclusion the water and space being limited inputs for fodder production, development of a system that produce high fodder yield is indeed essential at this juncture. Hydroponic fodder production becoming more and more common in countries where the outdoors is more vulnerable to climate change. It can be practiced in indoors and is more effective this way, as we can control the climate, and ensures a high yield. For arid, dry climates or areas with short growing season hydroponic thus holds a better solution.100\% Maize and $75 \%$ Maize $+25 \%$ Cowpea treatments are best to get higher biomass yield under hydroponic condition. 100\% Finger millet, $100 \%$ Little millet, $75 \%$ Finger millet $+25 \%$ Cowpea and $75 \%$ Little millet $+25 \%$ Cowpea treatments are best to get higher water productivity under hydroponic production system. $100 \%$ Maize and $75 \%$ Maize $+25 \%$
Cowpea are economically feasible treatments to get higher green fodder yield under hydroponic condition.

\section{References}

Al-Karaki, G. N. and Al-Hasimi, M., 2012, Green fodder production and water use efficiency of some forage crops under hydroponic condition. Int School of Res. Network. 40: 2-20.

Anonymous, 2012, Hydroponics green fodder feeding technology in Goa, Indian Council of Agricultural Research (Ministry of Agriculture and Farmers Welfare). www.icar.org.in.

Anonymous, 2017, Basic animal husbandry statistics. Department of Animal Husbandry, Dairying and Fisheries, Ministry of Agriculture, Govt. of India, Krishna Bhawan, New Delhi. pp. 1-152.

Dikshit, A. K. and Birthal, P. S., 2010, India's livestock feed demand: estimates and projections. Agric Economics Res. Rev., 3: 15-28

Dung, D. D., Gowdin, I. R. and Nolan, J. V., 2010, Nutrient content and in sacco degradability of barley grain and sprouted barley. J. Ani. Veter. Adv., 9(18): 2485-2492.

Mutumlamnganbi and Surve, U. S., 2017, Biomass yield and water productivity of different hydroponic fodder crops. J. Pharmacognosy Phytochemi., 6(5): 1297-1300.

Naik, P. K. and Singh, N. P.,2013, Hydroponics fodder production: an alternative technology for sustainable livestock production against impeding climate change. Model Training Course on Management Strategies for Sustainable Livestock Production against Impending Climate Change. Southern Regional Station, National Dairy Research Institute, Adugodi, 
Bengaluru, India: Pp. 70-75.

Naik, P. K. 2012, Hydroponics technology for fodder production. ICAR News, 18(3): 4.

Naik, P. K., Dhawaskar, B. D., Fatarpekar, D. D., Chakurkar, E. B. and Swain, B. K.,
2016, Nutrient changes with the growth of hydroponics cowpea (Vigna unguiculata) sprouts. Indian J. Animal nutr., 33: 357-359.

\section{How to cite this article:}

Sauvik Ganguly, B. S. Lalitha, Gurunath Raddy and Salman Khan, R. M. 2020. Influence of Combinations of Different Fodder Crops on Growth and Biomass Yield under Hydroponic Condition. Int.J.Curr.Microbiol.App.Sci. 9(09): 498-509. doi: https://doi.org/10.20546/ijcmas.2020.909.063 